УДК 619: 547.282: 615.282

(C) 2015

Передера С. Б., кандидат ветеринарних наук,

Кінаш О. В, аспірант

(науковий керівник - кандидат ветеринарних наук С. Б. Передера)

Полтавська державна аграрна академія

\title{
ВИЗНАЧЕННЯ ЧУТЛИВОСТІ ГРИБІВ РОДУ МUСОR TA ASPERGILLUS ДО ДЕЯКИХ РЕЧОВИН РОСЛИННОГО ПОХОДЖЕННЯ
}

\section{Рецензент - доктор ветеринарних наук, професор В. П. Бердник}

Наведено результати дослідження чутливості грибів роду Mисоr та Aspergillus до речовин, щзо мають рослинне походження (відвар трави ехінацеї пурпурової, екстракт ехінацеї рідкий, настоянка ехінацеї, ефірна олія базиліку, монарди, евгенол). У літературі наведено численні дані щзодо імуностимулюючої та бактерицидної дії вищезазначених речовин, однак дані стосовно їх фунгіицдних властивостей висвітлені недостатньо. Дослідження проводили стандартним диско-дифузійним методом. Використовували препарати ехінацеї пурпурової та ефірні олії з аптекарської мережі. Речовини рослинного походження перспективні для використання у ветеринарії, як альтернатива антибіотикам і дезінфектантам одночасно. Зокрема ефірні масла та їх компоненти можуть бути використані для сонації повітря птахівничих приміщень в якості дезінфікуючих засобів, а також, як речовини анаболічної та імуностимулюючої дї.

Ключові слова: гриби роду Мисог, гриби роду Aspergillus, препарати ехінацеї, ефірні олії, чутливість мікроорганізмів.

Постановка проблеми. Мікози є досить чисельною групою захворювань сільськогосподарських тварин і птиці. Зокрема патогенні гриби родів Mucor та Aspergillus широко розповсюджені в природі. Вони є досить стійкі до таких факторів, як УФ-опромінення, високі чи низькі температури. Для боротьби зі спорами патогенних грибків використовуються токсичні для людини і тварин речовини, що можуть як акумулюватися в організмі, так і забруднювати навколишне середовище. Профілактика та лікування грибкових інфекцій має два взаємодоповнюючі напрямки: знищення збудника в навколишньому середовищі та стимуляція імунної системи сприйнятливих до нього тварин.

Аналіз основних досліджень і публікацій, у яких започатковано розв'язання проблеми. Останнім часом чимало уваги надається вивченню екстрактів та інших фітопрепаратів (фітобіотиків) із нетрадиційних рослинних ресурсів для використання у ветеринарії [9]. Стимулом до пошуку нових альтернативних препаратів для тваринництва стала заборона антибіотиків-стимуляторів росту країнами Європейського Союзу. Речовини рослинного походження не викликають резистентності мікроорганізмів, алергічних, імунотоксичних і мутагенних ефектів навіть у разі тривалого застосування [4]. Найбільш ефективними для птахівництва вважаються препарати рослинних адаптогенів: елеутерокока, женьшеню, ехінацеї пурпурової [1]. Ехінацея пурпурова містить комплекс біологічно активних речовин, взаємодія яких обумовлює іiі високі адаптогенні властивості [1]. Ехінацея пурпурова в основному відома як імуностимулятор і використовується в Європі та Північній Америці для профілактики та лікування інфекційних захворювань, у тому числі у птиці $[5,7]$. Про компоненти рослин роду Echinacea, що мають протигрибкову активність i можуть бути використані у лікуванні мікозів повідомляють S. Merali, S. Binns, M. PaulinLevasseur $[10,11]$.

У нашій країні ефірні олії всебічно досліджувалися ще у 80-ті роки минулого століття спеціалістами гуманної медицини $[3,6]$. Так, В. В. Ніколаєвський всебічно дослідив більшість відомих ефірних олій не лише з точки зору їх бактерицидної дії, а й з боку впливу на макроорганізм. Він виявив, що найбільш вираженою антимікробною дією володіє масло монарди дудчастої та базиліку евгенольного, а також експериментально довів нешкідливість цих олій у хронічному експерименті на лабораторних тваринах [3]. Наразі запропоновано використовувати ефірні олії в якості засобів для дезінфекції інкубаційних яєць як таких, що не поступаються за ефективністю діï формаліну [7]. Встановлено фунгіцидний вплив водного екстракту 3 надземної частини Monarda didyma відносно фітопатогенного гриба Fusarium oxysporum. Антигрибкові властивості екстрактів рослин обумовлені передусім кількісним і якісним складом ефірних масел, які синтезують рослини [2]. Евгенол і карвакрол - скла- 


\section{ВЕТЕРИНАРНА МЕДИЦИНА}

дові багатьох ефірних масел, виділені як окремі препарати й рекомендовані для лікування орального кандидозу. Необхідні подальші дослідження їх фармакокінетичних і токсикологічних властивостей. Евгенол i карвакрол не викликають отруєння в щурів у терапевтичних дозах [8].

Мета дослідження: визначити чутливість грибів роду Mucor та Aspergillus до деяких речовин рослинного походження, що вірогідно мають імуностимулюючу та фунгіцидну дію.

Завдання дослідження: 3 обраних на основі вивчення літературних джерел речовин рослинного походження визначити такі, що мають найбільш виражений фунгіцидний вплив на гриби Aspergillus niger, Aspergillus flavus, Mucor ramosissimus.

Матеріали та методи дослідження. Виділення та ідентифікацію грибів Aspergillus niger, Aspergillus flavus, Mucor ramosissimus проводили за загальноприйнятими методиками. Визначення чутливості грибів здійснювали диско-дифузійним методом. Визначення кількості колонієутворюючих одиниць в 1 мл суспензії проводили за стандартною методикою в гемоцитометрі. Досліджувані речовини: відвар трави ехінацеї пурпурової, екстракт ехінацеї рідкий, настоянка ехінацеї, ефірна олія базиліку, монарди, евгенол (гвоздична олія).

Постановка досліду № 1. Для проведення досліду брали 5-7-денну чисту культуру грибів Aspergillus niger, Aspergillus flavus, Mucor ramosissimus і готували суспензію спор у фізіологічному розчині. Необхідна концентрація $1-5 \times 10^{6}$ КУО/мл. Кількість спор в 1 мл інокулюму визначали в гемоцитометрі за стандартною методикою. Суспензію спор у кількості 2 мл наносили на чашку Петрі $з$ агаром Сабуро і залишали для дифундування в агарі на 10 хвилин, зайву рідину збирали стерильною піпеткою. Після цього на поверхню середовища розміщували диски 3 фільтрувального паперу діаметром 6 мм, просочені досліджуваними розчинами. Чашки Петрі з посівами інкубували в термостаті догори дном за температури $25^{\circ} \mathrm{C}$. Облік реакції проводили на 24-у, 48-у та 72-у годину, аналізували діаметр зон затримки росту та характер росту.

Постановка досліду № 2. Було взято 4 окремі пробірки зі скошеним агаром Сабуро. Проводили висів 5-добової чистої культури Mucor ramosissimus у кожну пробірку, після чого на стінки пробірки кріпили диск, просочений ефірною олією монарди, евгенолом або ефірною олією базиліку. У цьому разі безпосередній контакт диску 3 поживним середовищем відсутній. Кількість спор в 1 мл інокулюму визначали в гемоцитометрі за стандартною методикою та використовували спори у концентрації - 1-5×106 КУО/мл. Остання пробірка без диску слугувала контролем. Облік реакції проводили через 24, 48 та 72 годин, аналізували характер росту та кількість спорангіїв у нативних мазках.

Результати досліджень. Результати досліду № 1. Характер росту у порівнянні 3 контролем неоднорідний, колонії плоскі, у Mucor ramosissimus та Aspergillus flavus повністю безбарвні, у Aspergillus flavus спостерігалося знебарвлення колоній у секторах взаємодії з ефірними маслами та евгенолом. Конідіальні голівки не утворювалися навіть у зоні росту на жодній із культур. Метод паперових дисків показав, що ефірна олія монарди та евгенол проявляють виражені фунгіцидні властивості по відношенню до дослідних культур грибків, зокрема найчутливішим виявився Mucor ramosissimus. Чутливість до настоянки ехінацеї має лише гриб Mucor ramosissimus. Це вказує на те, що серед означених речовин більш виражені фунгіцидні властивості мають ефірна олія монарди і евгенол і дещо менші - ефірна олія базиліку. Можна також стверджувати, що настоянка ехінацеї має фунгіцидний і фунгіостатичний вплив лише на окремі види патогенних грибків (див. рис.).

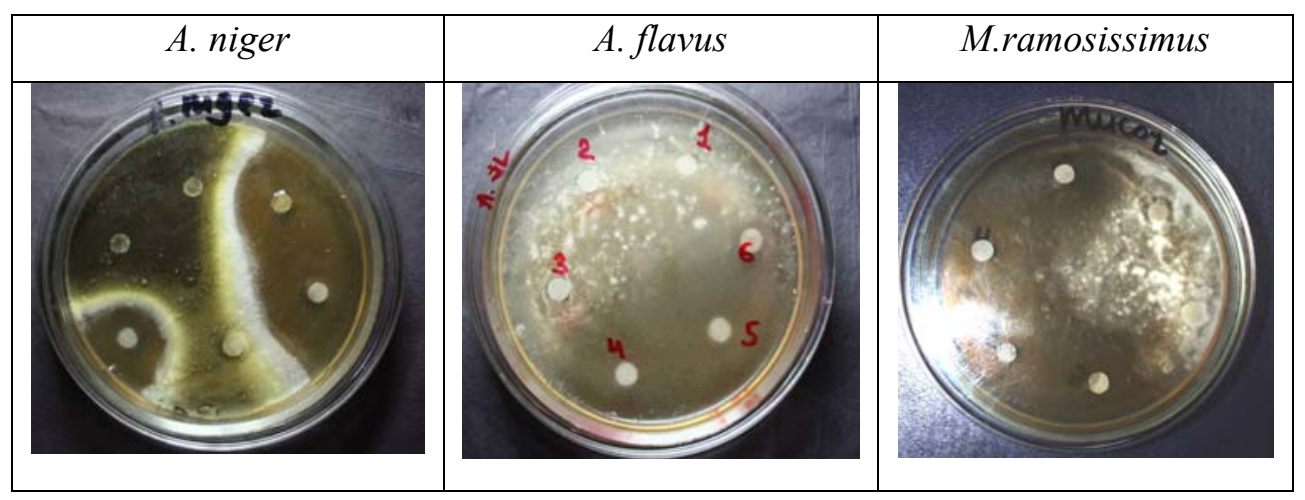

Рис. Визначення фунгіцидної активності досліджуваних речовин, 48 годин 
ВЕТЕРИНАРНА МЕДИЦИНА

1. Затримка росту дослідних культур

\begin{tabular}{|c|c|c|c|c|c|c|c|c|c|}
\hline \multirow{2}{*}{$\begin{array}{l}\text { Назва дослідної } \\
\text { речовини }\end{array}$} & \multicolumn{3}{|c|}{$\begin{array}{c}\text { Muсor ramosissimus, } \\
3,5 \times 10^{6} \mathrm{KУО/мл}\end{array}$} & \multicolumn{3}{|c|}{$\begin{array}{l}\text { Aspergillus niger } \\
4 \times 10^{6} \mathrm{KУО/МЛ}\end{array}$} & \multicolumn{3}{|c|}{$\begin{array}{c}\text { Aspergillus flavus } \\
3 \times 10^{6} \mathrm{KУО/МЛ}\end{array}$} \\
\hline & 24 год & 48 год & 72 год & 24 год & 48 год & 72 год & 24 год & 48 год & 72 год \\
\hline $\begin{array}{c}\text { Відвар трави } \\
\text { ехінацеї }\end{array}$ & ріст & ріст & ріст & ріст & ріст & ріст & ріст & ріст & ріст \\
\hline $\begin{array}{c}\text { Екстракт ехінацеї } \\
\text { рідкий }\end{array}$ & ріст & ріст & ріст & ріст & ріст & ріст & ріст & ріст & ріст \\
\hline $\begin{array}{c}\text { Настоянка } \\
\text { ехінацеї }\end{array}$ & $\begin{array}{l}40 \\
\pm 1 \\
\end{array}$ & $\begin{array}{c}22 \\
\pm 0,6 \\
\end{array}$ & $\begin{array}{c}17 \\
\pm 0,2 \\
\end{array}$ & $\begin{array}{c}6 \\
\pm 1,2 \\
\end{array}$ & $\begin{array}{c}2 \\
\pm 0,6 \\
\end{array}$ & ріст & ріст & ріст & ріст \\
\hline $\begin{array}{l}\text { Ефірна олія } \\
\text { монарди }\end{array}$ & $\begin{array}{c}50 \\
\pm 2,1\end{array}$ & $\begin{array}{c}50 \\
\pm 0,9\end{array}$ & $\begin{array}{c}50 \\
\pm 1,7\end{array}$ & $\begin{array}{l}35 \\
\pm 1\end{array}$ & $\begin{array}{c}31 \\
\pm 2,1\end{array}$ & $\begin{array}{c}26 \\
\pm 1,7\end{array}$ & $\begin{array}{l}35 \\
\pm 2\end{array}$ & $\begin{array}{c}33 \\
\pm 0,5\end{array}$ & $\begin{array}{c}30 \\
\pm 0,8\end{array}$ \\
\hline Евгенол & $\begin{array}{c}44 \\
\pm 1,4 \\
\end{array}$ & $\begin{array}{c}42 \\
\pm 0,1 \\
\end{array}$ & $\begin{array}{c}41 \\
\pm 0,2 \\
\end{array}$ & $\begin{array}{c}42 \\
\pm 1,3 \\
\end{array}$ & $\begin{array}{c}39 \\
\pm 0,8 \\
\end{array}$ & $\begin{array}{c}36 \\
\pm 1,5 \\
\end{array}$ & $\begin{array}{c}30 \\
\pm 1,3 \\
\end{array}$ & $\begin{array}{c}30 \\
\pm 0,9 \\
\end{array}$ & $\begin{array}{l}28 \\
\pm 1 \\
\end{array}$ \\
\hline $\begin{array}{l}\text { Ефірна олія } \\
\text { базиліку }\end{array}$ & $\begin{array}{c}40 \\
\pm 2,1\end{array}$ & $\begin{array}{c}39 \\
\pm 1,9\end{array}$ & $\begin{array}{c}39 \\
\pm 1,1\end{array}$ & $\begin{array}{c}35 \\
\pm 1,3\end{array}$ & $\begin{array}{c}31 \\
\pm 0,5\end{array}$ & $\begin{array}{c}30 \\
\pm 0,9\end{array}$ & $\begin{array}{c}20 \\
\pm 1,1\end{array}$ & $\begin{array}{c}17 \\
\pm 2,2\end{array}$ & $\begin{array}{c}14 \\
\pm 0,6\end{array}$ \\
\hline $\begin{array}{c}\text { Контроль } \\
\text { (фіз. розчин) }\end{array}$ & ріст & ріст & ріст & ріст & pict & ріст & ріст & ріст & pict \\
\hline
\end{tabular}

Результати досліду № 2. Через 24 години виявляли ріст у всіх пробірках, окрім верхньої частини стовпчика агару, що ближче до диску. В контрольній пробірці ріст рівномірний по всій поверхні агару. Колонії пухнасті, білого кольору, 3 добре розвиненим міцелієм. Через 48 годин у пробірці з диском, просоченим олією монарди, ріст був найменш вираженим, колонії білого кольору, пухнасті, в нижній частині пробірки міцелій димчатого кольору. В пробірках із дисками 3 евгенолом та ефірним маслом базиліку колонії мають дещо вищий міцелій, забарвлені в світло сірий колір. У контрольній пробірці міцелій високий, сірого кольору, в нижній частині пробірки

\section{БІБЛІОГРАФІЯ}

1. Бегма Л. О. Ефективність використання препарату ехінацеї пурпурової в птахівництві / Л. О. Бегма, Д. А. Бегма // Вісник ЛНАВМ ім. С. 3. Гжицького. - Львів, 2007. - Вип. 1(33), Т. 9. C. 3-6.

2. Котюк Л. А. Фунгіцидна активність екстрактів ефіроолійних рослин родини Lamifceae Lindl. відносно Fusarium Oxysporum / Л. А. Котюк, І. В. Іващенко // Біологічний вісник Мелітопольского державного педагогічного університету ім. Богдана Хмельницкого. - Мелітополь, 2013. - Вип. 3(9), Т. 3. - С.70-82.

3. Николаевский В. В., Еременко А. Е., Иванов И. К. дещо світліший.

У процесі мікроскопії матеріалу з дослідних пробірок виявляли зниження утворення кількості спорангіїв порівняно з контролем, основну масу становив міцелій.

Висновок. Виявлено високу фунгіцидну активність ефірної олії монарди та евгенолу. Відвар і екстракт трави ехінацеї не мають фунгіцидної дії на гриби родів Mucor та Aspergillus. Настоянка ехінацеї пурпурової має слабку протигрибкову активність проти грибів роду Aspergillus. Досліджені ефірні олії володіють фунгіостатичним ефектом для грибів роду Mucor навіть у разі відсутності безпосереднього контакту з культурою.

Биологическая активность эфирных масел / В. В. Николаевский, А. Е. Еременко, И. К. Иванов. М. : Медицина, 1987. - 144 с.

4. Патерега I. П. Протизапальна дія деяких фітопрепаратів при введенні всередину білим щурам / І. П. Патерега // Науково-технічний бюлетень Інституту біології тварин і Державного науково-дослідного контрольного інституту ветпрепаратів та кормових добавок. - Львів, 2008. Вип. 9, №4. - С. 131-134.

5. Самородов В.Н. Фитохимический состав представителей рода Эхинацея (Echinacea Moench) и его фармакологические свойства 


\section{ВЕТЕРИНАРНА МЕДИЦИНА}

(обзор) / [Самородов В. Н., Поспелов С. В., Моисеева Г. Ф. и др.] // Химико-фармацевтический журнал.- М. : изд-во «Фолиум», 1996. - №4. T. 30. - C. 32-37.

6. Талдыкин О. Е. Использование фитонцидной активности эфирных масел для оздоровления воздуха закрытых помещений / О. Е. Талдыкин // Фитонциды. Роль в біогеоценозах, значение для медицины. - К., 1981. - С. 201-203.

7. Ткаченко К. Г. Эфирные масла как средства дезинфекции в ветеринарии / [К. Г Ткаченко, Н. В. Казаринова, Н. А. Шкиль и др.] // Научные ведомости Белгородского государственного университета. Серия: Естественные науки. - Белгород, 2009. - Вып. 11 (66). - С. 65-71.

8. Chami N. Antifungal treatment with carvacrol and eugenol of oral candidiasis in immunosuppressed rats / N. Chami, F. Chami, S. Bennis, J. Trouillas, A. Remmal // Brazilian
Journal of Infectious Diseases. - 2004. - V. 8, №3.P. 217-226.

9. Kumar K. M. Pharmacological importance of Echinacea purpurea / K. M. Kumar, Sudha Ramaiah // International Journal of Pharma and Bio Sciences. 2011. -V. 2, №4. - P. 304-314.

10. Landy $N$. The effects of Echinacea purpurea L. (purple coneflower) as an antibiotic growth promoter substitution on performance, carcass characteristics and humoral immune response in broiler chickens. / N. Landy, Gh. Ghalamkari, M. Toghyani, F. Moattar // Full Length Research Paper. Journal of Medicinal Plants Research. 2011. - V. 5 (11). - P. 2332-2338.

11. Merali $S$. Antifungal and anti-inflammatory activity of the genus Echinacea / [S. Merali, S. Binns, M. Paulin-Levasseur et al.] // Pharmaceutical Biology. - 2003. - V. 41, №6. P. 412-420. 